\title{
PILOT STUDY OF RISK GROUP HUMAN SEROPREVALENCE TO COXIELLA BURNETII (Q FEVER) IN LATVIA
}

\author{
Lelde Grantiṇa-leviṇa $^{1, \#}$, Ilga Bubula ${ }^{1}$, Maija Sergejeva ${ }^{1}$, Žanete Šteingolde ${ }^{1}$, \\ Guntis Boikmanis ${ }^{1}$, Dina Cīrule ${ }^{1}$, Kaspars Kovalenko ${ }^{2}$, Vita Antāne ${ }^{2}$, and Aivars Bērziṇš ${ }^{1}$ \\ 1 Institute of Food Safety, Animal Health and Environment "BIOR", 3 Lejupes Str., Rīga, LV-1076, LATVIA \\ ${ }^{2}$ Faculty of Veterinary Medicine, Latvia University of Life Sciences and Technologies, 8 Kristapa Helmaṇa Str., Jelgava, LV-3004, \\ LATVIA \\ \# Corresponding author, lelde.grantina-ievina@bior.lv
}

Contributed by Aivars Bērziṇš

\begin{abstract}
$Q$ fever is an important zoonotic disease worldwide. The main sources of human infection are inhalation of aerosols containing Coxiella burnetii bacteria and exposition to infected materials during parturition or slaughtering. The high-risk group includes people who work directly with infected livestock, such as farmers, veterinarians, veterinary medicine students, slaughterhouse and laboratory staff. Here we present a pilot study of risk-group human seroprevalence to C. burnetii in Latvia. The study included 240 sera samples - 190 from the risk groups and 50 from the control group. Samples were tested with Coxiella burnetii (Q-fever) Phase 1 and 2 IgG ELISA kits. All sera from the control group were negative. The seroprevalence among risk group persons was 8.04-11.54\%. No statistically significant differences were observed between genders. The highest percentage of seropositive and equivocal sera samples (25\%) were detected in age categories 39-48 years and 49-58 years. Working as a practicing veterinarian or former veterinarian was the only risk factor identified as statistically significant, and belonging to the risk group in general. The geographical distribution of seropositive risk group participants indicated that they tend to located more in the northern, central, and eastern part of the country.
\end{abstract}

Key words: coxiellosis, occupational risk, people, public health, zoonotic disease.

\section{INTRODUCTION}

Q fever is a common zoonotic disease in Europe, as well as in Latvia. At least $13.2 \%$ of dairy cow sheds tested positive for presence of Coxiella burnetii antibodies in bulk tank milk in 2015 (Boroduske et al., 2017). The Q fever causing agent is a small bacterium, C. burnetii, a mandatory intracellular pathogen, able to multiply only in the cells of a living organism. It enters cells when the animal's immune cell absorbs the bacteria. Usually, the microorganisms that enter the cells in this way are destroyed, but the Q fever agent creates a specific vesicular structure inside the cell, called the parasitic vacuole, and maintains viability. Outside the host (human or animal), the bacterium $C$. burnetii is in an inactive state and forms spores, or the so-called small cell variant, which helps the bacterium to survive in adverse environmental conditions. In turn, in the host, through the parasitic vacuole, it forms a highly infectious and metaboli- cally active large cell variant (Maurin and Raoult, 1999; Voth and Heinzen, 2007; Larson et al., 2015). Bacteria then spread through the bloodstream (Shannon and Heinzen, 2009).

There are two forms of antigens for this bacterium: the pathogenic Phase I (PhI), which can be isolated from infected animals and humans, and the attenuated form of Phase II (PhII), which can be obtained by repeated passages in embryonated eggs or in vitro. In repeated passages, changes occur in the lipopolysaccharide chain. Lipopolysaccharide is a major factor of virulence. Full-length PhI lipopolysaccharides, which block the binding of antibodies to surface proteins, result in truncated forms of lipopolysaccharide-containing PhIIs, which are readily accessible to antibodies. Thus, PhII antibodies are present in all forms of infection and at every stage (Fournier et al., 1998; OIE, 2018). PhII-specific antibodies (IgM, IgG) predominate in 
acute infection, and $\mathrm{PhI}$-specific antibodies ( $\operatorname{IgG}, \operatorname{Ig} \mathrm{A})$ predominate in chronic disease (Angelakis and Raoult, 2010).

The high-risk group includes people who work directly with infected livestock, such as farmers, veterinarians, veterinary medicine students, slaughterhouse and laboratory staff, etc. (Graham et al., 1989; Armengaud et al., 1997; Valencia et al., 2000; Bosnjak et al., 2010; de Rooij et al., 2012). Direct contact with infected livestock in their holdings, sales outlets, or slaughterhouses is considered to be the main form of $\mathrm{Q}$ fever infection. The risk also includes direct contact with the birth or abortion materials of infected animals, noncompliance with personal protective equipment and measures (gloves, change of clothing, hand washing), contact with manure, shearing of sheep, and inhalation of bacterial aerosols and dust from faeces of infected animals, urine, milk, tissue fluids, etc. (Le Jeune and Kersting, 2010; Agerholm, 2013). In an investigation in Eastern Poland it was determined that $16.2 \%$ of hunters were seropositive against C. burnetii (Tokarska-Rodak et al., 2018). People living in the vicinity of infected farms are also at risk, as bacteria are spread by wind together with dust from animal housing (Van der Hoek et al., 2011a; Barlozzari et al., 2020). The prevalence of wind and dust has been indirectly demonstrated in the Netherlands by analysing one of the largest Q-fever outbreaks in history in 2008 and 2009, covering more than 3300 reported human cases (Le Jeune and Kersting, 2010). In connection with these outbreaks, another study demonstrated the presence of C. burnetii DNA in dust (Hogerwerf et al., 2012). The role of wind-displaced aerosols in human Q-fever outbreaks was demonstrated in France as well (Tissot-Dupont et al., 2004).

The disease can be transmitted from person to person through airborne droplets (aerosols), contact with infected postnatal tissue material, and sexual contact. Q fever belongs to nosocomial infections - cases have been reported in immunocompromised people during hospitalisation (Milazzo et al., 2001; Osorio et al., 2003; Parker et al., 2006; Amit et al., 2014). Immunodepression can increase the possibility for clinical outcomes of the infection like hepatitis and pneumonia, but this risk factor is less common in comparison to rural life, occupational exposure, contact with animals, or raw cheese or milk consumption (Raoult et al., 2000). Q fever transmission through blood transfusion and bone marrow transplantation is also possible (Kanfer et al., 1988; Kersh et al., 2013; Oei et al., 2014; Slot et al., 2014). Data on Q fever infection by ingested infected unpasteurised milk and dairy products are contradictory. It is considered that pasteurisation should be used to kill the Q fever agent in fresh milk (Huebner and Jellison, 1949; Gale et al., 2015; Eldin et al., 2016).

Q-fever in humans can occur in both acute and chronic forms. This bacterium is especially dangerous for pregnant women, as it can cause abortion or premature birth (Maurin and Raoult, 1999). Studies in Bulgaria and the Netherlands have shown exposure to $\mathrm{Q}$ fever in $7.7 \%$ and $9.1 \%$ of pregnant women, respectively (Georgiev et al., 2013). In a study in the Netherlands, a study of pregnant women from high- risk areas found that 3.4\% had a recent $\mathrm{Q}$ fever infection (IgM-type antibodies) (Van der Hoek et al., 2011b).

According to data of the Centre for Disease Prevention and Control of Latvia, from the period from 2015 till 2019, there was on average one registered human case per year. One case was identified in the first quarter of 2020 (SPKC, 2020). Numbers of registered human cases in European Union (EU) increased every year in the period from 2012 (518 cases) till 2016. There were 1057 registered human cases from 19 member states in 2016. Spain was the country that reported the most cases (331), followed by Germany and France (270 and 251, respectively). Forty-eight cases were reported by Switzerland and two cases were reported by Norway (EFSA and ECDC, 2017). The incidence of the disease in Europe was 0.2 cases per 100000 population in 2017 (ECDC, 2019). Since the disease can be in a light form, similar to common cold or flu, the real numbers of infected people could be much higher. A good illustration of this was Q-fever outbreak in the Netherlands with 3500 notified cases between 2007 and 2009 (van der Hoek et al., 2010) and possibly more than 40000 infections (Kampschreur et al., 2013).

The aim of the present study was to detect the seroprevalence to $C$. burnetii in Latvia among various risk groups (animal owners and farmers, veterinarians and veterinary medicine students, and slaughterhouse personnel), and a control group - people living in the capital of Latvia without strong connection to countryside.

\section{MATERIALS AND METHODS}

Participants. The study was approved by the Ethics Committee of the Institute of Food Safety, Animal Health and Environment "BIOR" (opinion No. 2/10/5/2019). In total, 162 voluntary participants over age 18 participated in the study (Table 1). Blood samples were taken during January and February 2020. All participants had to fill in a questionnaire with the following questions: gender and age; whether he/she is a practicing veterinarian or a former veterinarian; if yes, how long; whether he/she is a farmer or owner of animals (cattle, goats, sheep); if yes, how long; whether he/she is currently or has been a slaughterhouse worker; if yes, how long; which animal species has he/she worked with or had worked with - cattle, goats, sheep; in which town / region is the farm or workplace located. Female participants were asked to indicate whether they are pregnant at the moment of the survey.

Table 1. Number of participants in the risk and control groups

\begin{tabular}{l|c|c|c|c}
\hline Group & $\begin{array}{c}\text { Total } \\
\text { number, } \\
\mathrm{n}\end{array}$ & $\begin{array}{c}\text { Male, } \\
\mathrm{n}(\%)\end{array}$ & $\begin{array}{c}\text { Female/ } \\
\text { including } \\
\text { pregnant, } \mathrm{n}(\%)\end{array}$ & $\begin{array}{c}\text { Average age } \\
\text { (variation) }\end{array}$ \\
\hline Risk group I & 112 & $23(20.54)$ & $89 / 3(79.46)$ & $36.39(19-70)$ \\
Risk group II & 78 & $21(26.92)$ & $57 / 1(73.08)$ & $46.44(21-79)$ \\
Control group & 50 & $12(24.00)$ & $38 / 2(76.00)$ & $41.86(21-78)$
\end{tabular}




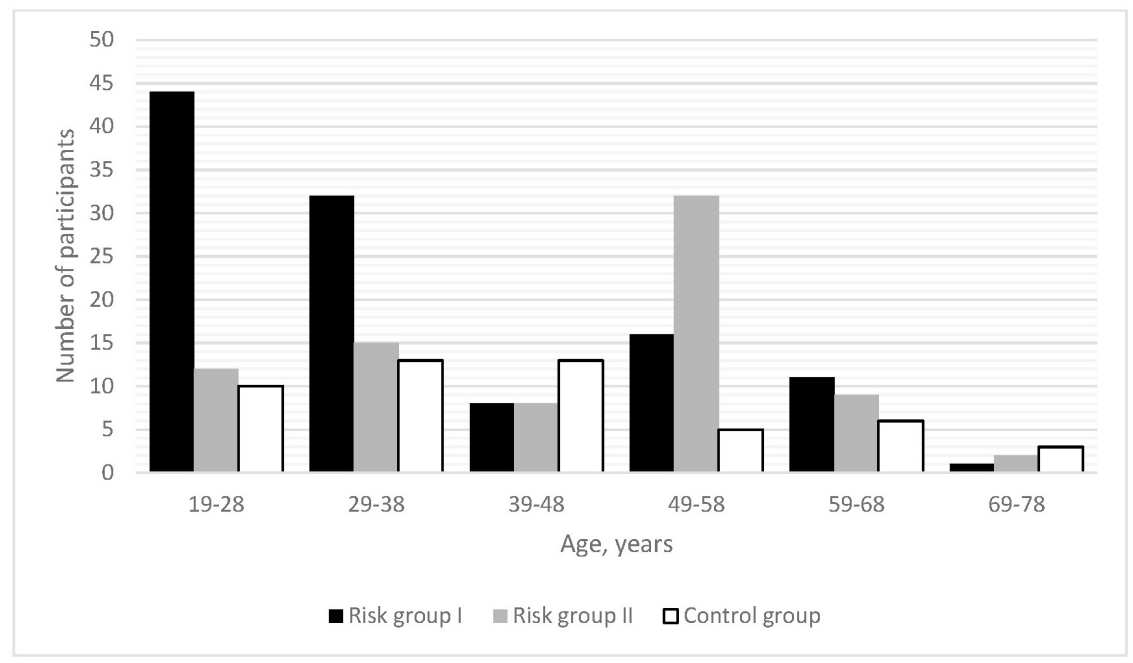

Fig. 1. Distribution of participants by age groups in risk groups I and II ( $\mathrm{n}=190)$, and in the control group $(n=50)$.
Distribution of participants by age groups is given in Figure 1. Participants of the risk group (Risk group I, 112 people) were veterinarians, veterinary medicine students, animal owners and farmers, people who had worked in the past or are working at the moment in slaughterhouse, and laboratory staff from veterinary laboratories. They were invited to participate in the investigation, and blood samples were taken during a conference in November 2019. In several cases, veterinarians and veterinary medicine students were also animal owners themselves or together with family, or had connection with a slaughterhouse, so they belonged to several risk groups at the same time.

The control group consisted of 50 people from one family doctor practice located in the capital of Latvia, Rīga. Two persons, age 39 and 42, indicated that they had lived in a farm in childhood. One person indicated that his/her father was a veterinarian. One person indicated that he/she has cattle and pigs and slaughters animals two to three times per year. In total five people within the control group indicated that they had previous contact with cattle, and of these two persons had contact with sheep as well, and one person had contact with goats. Other control group participants declared no contacts with ruminants, and none of them were veterinarians or slaughterhouse workers.

Risk group II included veterinarians who had daily contact with farm animals and samples or products of their origin at the place of residence and working place $(n=35)$ or daily contact only at the working place $(n=43) .78$ serum samples were stored in the sample collection of the Institute of Food Safety, Animal Health and Environment "BIOR" obtained in the European Regional Development Fund "Postdoctoral research aid" project "One Health multidisciplinary approaches for epidemiology and prevention of selected parasitic zoonosis" (OMEPPAZ) (1.1.1.2/VIAA/1/16/204).

After sampling, blood samples were stored at 4 to $6{ }^{\circ} \mathrm{C}$ temperature, but later serum samples were stored at $-20{ }^{\circ} \mathrm{C}$ temperature.

Methods. Blood serum samples were tested with Coxiella burnetii (Q-fever) Phase 1 IgG ELISA and Coxiella burnetii
(Q-fever) Phase 2 IgG ELISA kits (NovaTec Immundiagnostica $\mathrm{GmbH}$, Germany) according to the manufacturer recommendations. Positive and suspicious samples were tested twice. According to the information provided by the manufacturer, the diagnostic sensitivity of both tests is $100 \%$ and diagnostic specificity of both tests is $100 \%$. Results were evaluated as negative, positive, and suspicious (equivocal).

Statistical analyses. Statistical analyses were performed using the chi-squared test (Social Science Statistics, 2020). Odds ratio and the $95 \%$ confidence intervals for disease prevalence were calculated by the WilsonCL algorithm (Brown et al., 2001) using the open access program Epitools (Estimated true prevalence...).

\section{RESULTS}

All sera from the control group were negative (95\% CI: 0-7.13). Within the Risk group I, three blood sera were positive to Phase I IgG antibodies and one was suspicious (Table 2). These samples were from practicing veterinarians, age 30 to 59, and with work experience of 2.5 to 26 years. Three of them were also livestock farmers or animal owners. One of the veterinarians indicated in the questionnaire that he/she had not worked with ruminants. None of the seropositive veterinarians had worked in a slaughterhouse.

Within the Risk group I, six blood sera were positive to Phase II IgG antibodies and seven were suspicious. None of the samples were positive to both phase antibodies at the same time. Seropositive persons were practicing veterinarians with work experience from one to 34 years, three were

Table 2. Seroprevalence to $C$. burnetii in the risk and control groups

\begin{tabular}{lcc}
\hline Group & $\begin{array}{c}\text { Phase I IgG positive/ } \\
\text { suspicious }\end{array}$ & $\begin{array}{c}\text { Phase II IgG positive/ } \\
\text { suspicious }\end{array}$ \\
\hline Risk group I & $3 / 1$ & $6 / 7$ \\
Risk group II & $7 / 4$ & $3 / 2$ \\
Control group & $0 / 0$ & $0 / 0$ \\
Total & $10 / 5$ & $9 / 9$
\end{tabular}




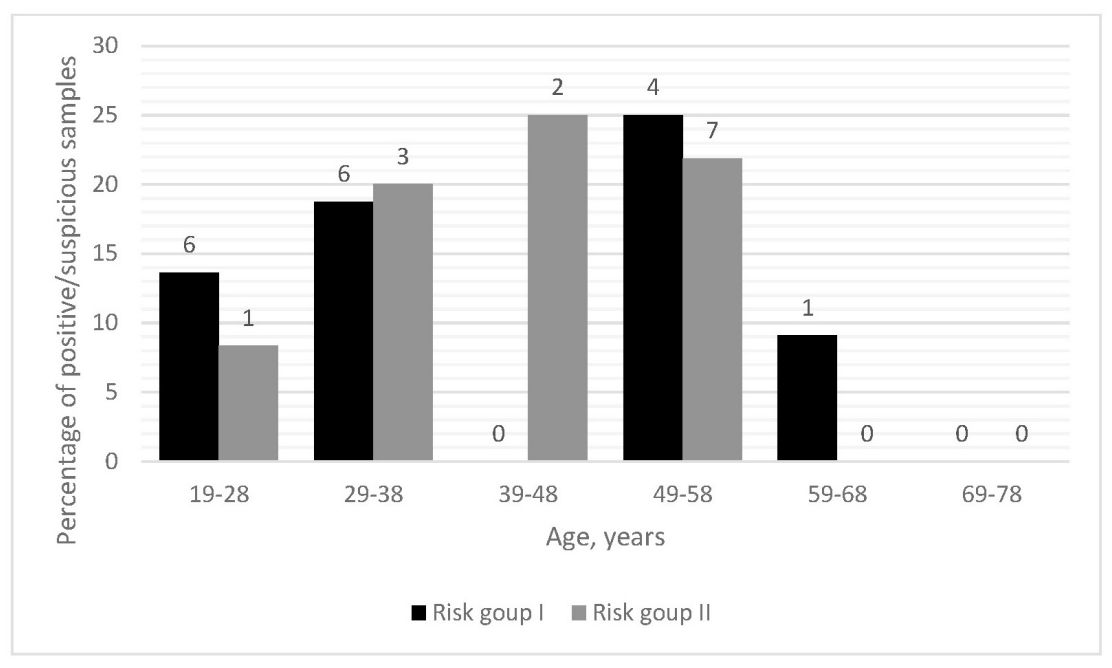

Fig. 2. Distribution of seropositive and suspicious participants by age groups of the risk groups I and 2 $(n=190)$ in percentages; absolute numbers are indicated above the bars.

veterinary students, and one was a laboratory expert. One of the positive persons was pregnant. The age of seropositive participants ranged from 23 to 58 years. Three of them were also livestock farmers or animal owners. One person worked in a slaughterhouse for 33 years. Two participants declared that they had never worked with ruminants.

The overall seroprevalence among Risk group I persons was nine positive sera from 112 participants $(8.04 \%$, 95\% confidence interval (CI): 4.29-14.57), but including suspicious samples - 15.18\% (17/112; 95\% CI: 9.70-22.97). Seroprevalence in the Risk group I did not statistically significantly differ between the sample groups of women and men, $15.73 \%$ and $13.04 \%$, respectively $\left(\chi^{2}\right.$ statistics with Yates correction $\left.-\chi^{2}=0, p=0.99\right)$. Distribution of seropositive and suspicious participants in numbers by age groups is given in Figure 2 and it was statistically not significant $\left(\chi^{2}\right.$ statistics $\left.-\chi^{2}=1.66, p=0.65\right)$. The highest seroprevalence as a percentage of participants in the risk group was in the 49-58-year age group - 25\% (Fig. 2), and the difference in percentage among age groups was statistically significant $\left(\chi^{2}\right.$ statistics $\left.-\chi^{2}=10.09, p=0.02\right)$.

Among the samples from Risk group II, there was one seropositive sample and one sample was suspicious to the antibodies of both phases. One sample was positive to Phase I IgG antibodies and suspicious to Phase II IgG antibodies. The overall seroprevalence among Risk group II persons was nine positive sera of 78 samples $(11.54 \%, 95 \% \mathrm{CI}$ : 6.19-20.50), but including suspicious samples - $16.67 \%$ (13/78; 95\% CI: 10.01-26.46). Seroprevalence in the Risk group II did not statistically significantly differ between sample groups of women and men, $15.79 \%$ and $7.02 \%$, respectively $\left(\chi^{2}\right.$ statistics with Yates correction $-\chi^{2}=0, p=$ $1.00)$. Distribution of seropositive and suspicious participants in numbers by age groups is given in Figure 2 and it was statistically not significant $\left(\chi^{2}\right.$ statistics $-\chi^{2}=1.66$, $p=0.65)$. The highest seroprevalence as a percentage of participants in the risk group was in the 39-48-year age group - $25 \%$ (Fig. 2), and the difference in percentage among age groups was statistically significant $\left(\chi^{2}\right.$ statistics $\left.-\chi^{2}=10.95, p=0.01\right)$. Differences between veterinarians who had daily contact with farm animals and samples or

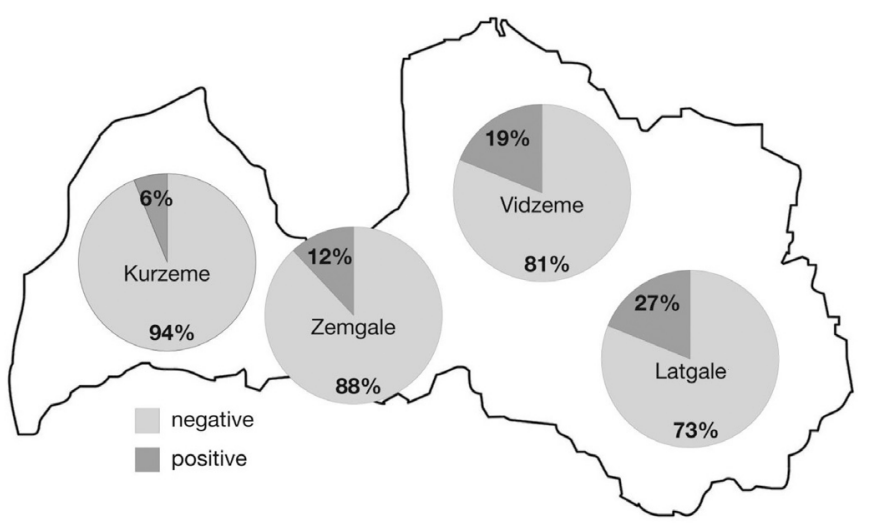

Fig. 3. The geographical distribution of seropositive and suspicious (indicated together as positive) risk group I and II participants as percentages of all participants according to their working and living places.

products of their origin at the place of residence and working place $(n=35)$ or daily contact only at the working place $(\mathrm{n}=43)$ were statistically not significant $\left(\chi^{2}\right.$ statistics $\left.\chi^{2}=1.25, p=0.26\right)$.

The geographical distribution of seropositive and suspicious risk group participants as percentage from all participants in terms of their working and living places is given in Figure 3. The highest percentage of seropositive and suspicious risk group participants summed together was in the eastern part of Latvia (Latgale) - $27 \%$ and the lowest $(6 \%)$ in the western part of the country (Kurzeme).

Prevalence and odds of testing seropositive or suspicious for $C$. burnetii antibodies in Risk group I and control group depending on particular risk factors is given in Table 3. Only one variable had a statistically significant $p$ value working as practicing veterinarian or former veterinarian $(p=0.03)$, and belonging to the Risk group I in general ( $p=$ $0.01)$.

\section{DISCUSSION}

The current investigation is the first study on Q-fever seroprevalence among the human population in Latvia. As a pi- 
Table 3. Prevalence and odds of testing seropositive or suspicious for C. burnetii antibodies in Risk group I and control group

\begin{tabular}{|c|c|c|c|c|}
\hline Variable & Total/positive & Prevalence \% $(95 \% \mathrm{CI})$ & Odds ratio $(95 \% \mathrm{CI})$ & $p$-value* \\
\hline Risk group I & $112 / 17$ & $15.18(9.70-22.97)$ & $18.51(1.09-314.17)$ & 0.01 \\
\hline Practicing veterinarian or a former veterinarian & $78 / 13$ & $16.67(10.01-12.38)$ & $3.85(1.2-12.38)$ & 0.03 \\
\hline Farmer or owner of animals (cattle, goats, sheep) & $53 / 6$ & $10.71(5.29-22.58)$ & $1.14(0.4-3.26)$ & 1.00 \\
\hline Is currently or has been a slaughterhouse worker & $18 / 2$ & $11.11(3.1-32.8)$ & $1.07(0.22-5.14)$ & 1.00 \\
\hline Worked with cattle & $97 / 14$ & $14.43(8.8-22.78)$ & $3.49(0.96-12.66)$ & 0.08 \\
\hline Worked with goats & $41 / 6$ & $14.63(6.88-28.44)$ & $1.71(0.59-4.97)$ & 0.48 \\
\hline Worked with sheep & $59 / 6$ & $10.17(4.74-20.46)$ & $0.95(0.33-2.71)$ & 1.00 \\
\hline Pregnant at the moment of the survey & $5 / 1$ & $20(3.62-62.45)$ & $0.12(0-4.61)$ & 0.58 \\
\hline
\end{tabular}

* Yates corrected Chi-square

lot study it provides insight into the situation of Q-fever seroprevalence among risk groups and the general population.

According to the literature, the main sources of human infection are inhalation of aerosols containing $C$. burnetii bacteria and exposure to infected materials during parturition or slaughtering. Wind can transmit the bacteria for at least 30 $\mathrm{km}$ away from the source. Other routes of human infection can be intradermal inoculation, consumption of infected food, human-to-human transmission, and possibly by ticks. Although the pathway of bacterial transmission in the human population by ticks has not been proven (Eldin et al., 2017; Koehler et al., 2019), the role of ticks cannot be excluded (Borawski et al., 2020). Laboratory acquired infections have also been documented (Koehler et al., 2019). The infection dose in humans is very low - only 1.18 bacteria, and the dose for the illness is 5.58 bacteria (Brooke et al., 2013).

In the present study it was shown that among the participants from the general population (control group) there were no seropositive persons, in contrast to the risk groups in which 8 to $11 \%$ of serum samples were seropositive. The number of control group samples in the study was smaller than the number of risk group samples. Possibly, by increasing the number of control group samples tested, the results would be similar to the study in Estonia where 3.9\% seroprevalence was detected among the general adult population, testing 1000 samples from the biobank of the Estonian Genome Centre (Neare et al., 2019).

Only one risk factor gave a statistically significant $p$ value - working as practicing veterinarian or former veterinarian ( $p=0.03$ ), and belonging to the Risk Group I in general $(p=0.01)$. A similar seroprevalence level among veterinary professionals and dairy cattle farmers was detected in an investigation in a neighbouring country, Estonia - 9.62\% and $7.73 \%$, respectively. However, the seroprevalence in the general population was $3.9 \%$ and it did not statistically differ from other risk groups - beef farmers, small ruminant farmers, and hunters. Statistically significant differences were not observed between genders and among various age groups (Neare et al., 2019). The observed seroprevalence in Latvia and Estonia is significantly lower than in other countries. For example, in a recent study in France, the seroprevalence rate among veterinarians was $88.9 \%$, among cattle farmers - 56.3\% and among blood donors - $12.7 \%$ (Pouquet et al., 2020). In a risk group study of farm workers in Poland, the seroprevalence detected by ELISA was 39.07\% (Szymańska-Czerwińska et al., 2015).

In the present study, statistically significant differences were obtained between various age categories in both risk groups. The highest percentage of seropositive and suspicious samples $(25 \%)$ was detected in age groups 39-48 years and 49-58 years, in risk groups II and I, respectively. In a study in the Northern Ireland, the highest seroprevalence was observed in the age group 25-34 years (McCaughey et al., 2008).

The seroprevalence to the Phase I and Phase II IgG was similar in our investigation, indicating equal levels of acute infection and chronic disease among risk group persons. We do not have information on the health status of the study participants, so it is not known how many of them have had symptoms, and how many have had the disease without symptoms.

The geographical distribution of seropositive risk group I and II participants indicates that they are located more in eastern (Latgale), northern (Vidzeme) and central (Zemgale) parts of Latvia (Fig. 3). This corresponds to previously published data about risk areas in spatial distribution of Qfever infected dairy cow sheds, which were less numerous in the western part of the country. In that investigation, the regional cattle shed density was found to be a significant risk factor for the presence of $C$. burnetii DNA among dairy cattle bulk tank milk samples (Boroduske et al., 2017). We can assume that increased cattle population density can increase the infection risk with Q-fever for veterinary professionals working in those areas as well. Therefore, it is very important to implement and to apply proper biosafety measures and protocols in all cattle farms to limit the introduction and spread of Q-fever (EFSA, 2010). Measures to reduce human exposure include a ban on visitors to infected farms and the use of personal protective equipment by farm and slaughterhouse workers (Mori and Roest, 2018). 
Australia is the only country with vaccination experience among risk group persons, stated in 1989, and a more broader vaccination programme began in 2002. Immunisation was used for veterinarians, veterinary students, veterinary nurses, and slaughterhouse workers. After the vaccination programme in 2002, the number of reported cases in the human population decreased by $50 \%$ (Eldin et al., 2017). In a recent study in Australia, while assessing the seroprevalence to $C$. burnetii antibodies among unvaccinated veterinary workers, it was found that $19 \%$ of all participants had antibodies. The authors concluded that these findings clearly illustrate the need for vaccination of veterinary workers (Sellens et al., 2020). Similarly, we could advise to register and apply vaccination for the human population also in Europe.

\section{CONCLUSIONS}

As Q-fever is a widespread disease in dairy farms in Latvia, the results of the study are logical - more than $10 \%$ of the representatives of risk groups had been exposed to the disease-causing agent or have had the Q-fever, resulting in antibody formation. More research with a larger part of the population is needed in the future as well as education of risk group persons in order to improve public health.

\section{ACKNOWLEDGMENTS}

This research was funded by the Latvian Council of Science project "Impact of zoonosis $Q$ fever on reproduction of dairy cattle and solutions for the disease control and sustainable use of animals", project No. lzp-2018/2-0109.

\section{REFERENCES}

Agerholm, J. S. (2013). Coxiella burnetii associated reproductive disorders in domestic animals: A critical review. Acta Vet. Scand., 55 (1), 13.

Amit, S., Shinar, S., Halutz, O., Atiya-Nasagi, Y., Giladi, M. (2014). Suspected person-to-person transmission of $\mathrm{Q}$ fever among hospitalized pregnant women. Clin. Infect. Dis., 58 (11), e146-e147.

Angelakis, E., Raoult, D. (2010). Q Fever. Vet. Microbiol., 140 (3-4), 297-309.

Armengaud, A., Kessalis, N., Desenclos, J. C., Maillot, E., Brousse, P., Brouqui, P., Tixier-Dupont, H., Raoult, D., Provensal, P., Obadia, Y. (1997). Urban outbreak of Q fever, Briançon, France, March to June 1996. Euro Surveill., 2 (2), 137.

Barlozzari, G., Sala, M., Iacoponi, F., Volpi, C., Polinori, N., Rombolá, P., Vairo, F., Macrì, G., Scarpulla, M. (2020). Cross-sectional serosurvey of Coxiella burnetii in healthy cattle and sheep from extensive grazing system in central Italy. Epidemiol. Infect., 148, e9, 1-8.

Bosnjak, E., Hvass, A. M. S. W., Villumsen, S., Nielsen, H. (2010). Emerging evidence for $\mathrm{Q}$ fever in humans in Denmark: role of contact with dairy cattle. Clin. Microbiol. Infec., 16 (8), 1285-1288.

Borawski, K., Dunaj, J., Czupryna, P., Pancewicz, S., Świerzbińska, R., Żebrowska, A., Moniuszko-Malinowska, A. (2020). Assessment of Coxiella burnetii presence after tick bite in north-eastern Poland. Infection, 48, 85-90.

Boroduske, A., Trofimova, J., Kibilds, J., Papule, U., Sergejeva, M., Rodze, I., Grantina-Ievina, L. (2017). Coxiella burnetii (Q fever) infection in dairy cattle and associated risk factors in Latvia. Epidemiol. Infect., 145 (10), 2011-2019.

Brooke, R. J., Kretzschmar, M. E., Mutters, N. T., Teunis P. F. (2013). Human dose response relation for airborne exposure to Coxiella burnetii. BMC Infect. Dis., 13, 488.

Brown, L. D., Cat, T. T., DasGupta A. (2001). Interval estimation for a binominal proportion. Stat. Sci., 16 (2), 101-133.

de Rooij, M. M. T., Schimmer, B., Versteeg, B., Schneeberger, P., Berends, B. R., Heederik, D., van der Hoek, W., Wouters, I. M. (2012). Risk factors of Coxiella burnetii ( $\mathrm{Q}$ fever) seropositivity in veterinary medicine students. PLOS ONE, 7 (2), e32108.

ECDC (European Centre for Disease Prevention and Control). (2019). Q Fever. In: Annual Epidemiological Report for 2017. ECDC, Stockholm, pp. $1-6$.

EFSA (European Food Safety Authority) and ECDC (European Centre for Disease Prevention and Control). (2017). The European Union summary report on trends and sources of zoonoses, zoonotic agents and food-borne outbreaks in 2016. EFSA Journal, 15 (12), 5077.

EFSA (European Food Safety Authority) Panel on Animal Health and Welfare (AHAW). (2010). Scientific Opinion on Q Fever. EFSA Journal, 8 (5), 1595.

Eldin, C., Mélenotte, C., Mediannikov, O., Ghigo, E., Million, M., Edouard, S., Mege, J. L., Maurin, M., Raoul, D. (2017). From Q fever to Coxiella burnetii infection: A paradigm change. Clin. Microbiol. Rev., 30 (1), 115-190.

Estimated true prevalence and predictive values from survey testing. https://epitools.ausvet.com.au/trueprevalence (accessed 20.08.2021).

Fournier, P. E., Marrie, T. J., Raoult, D. (1998). Diagnosis of Q fever. J. Clin. Microbiol., 36 (7), 1823-1834.

Gale, P., Kelly, L., Mearns, R., Duggan, J., Snary, E. L. (2015). Q fever through consumption of unpasteurised milk and milk products: A risk profile and exposure assessment. J. Appl. Microbiol., 118 (5), 1083-1095.

Georgiev, M., Afonso, A., Neubauer, H., Needham, H., Thiéry, R., Rodolakis, A., Roest, H. J., Stärk, K. D., Stegeman, J. A., Vellema, P., van der Hoek, W., More, S. J. (2013). Q fever in humans and farm animals in four European countries, 1982 to 2010. Euro Surveill. 18 (8), 20407.

Graham, C. J., Yamauchi, T., Rountree, P. (1989). Q fever in animal laboratory workers: An outbreak and its investigation. Amer. J. Infect. Control, 17 (6), 345-348.

Huebner, R. J., Jellison, W. L. (1949). Q fever studies in Southern California. III. Effects of pasteurization on survival of $C$. burneti in naturally infected milk. Public Health Rep., 64 (16), 499-511.

Hogerwerf, L., Borlée, F., Still, K., Heederik, D., van Rotterdam, B., de Bruin, A., Nielen, M., Wouters, I. M. (2012). Detection of Coxiella burnetii DNA in inhalable airborne dust samples from goat farms after mandatory culling. Appl. Environ. Microbiol., 78 (15), 5410-5412.

Kampschreur, L., Hagenaars, J., Wielders, C., Elsman, P., Lestrade, P., Koning, O., Oosterheert, J., Renders, N., Wever, P. (2013). Screening for Coxiella burnetii seroprevalence in chronic Q fever high-risk groups reveals the magnitude of the Dutch Q fever outbreak. Epidemiol. Infect., 141 (4), 847-851.

Kanfer, E., Farrag, N., Price, C., MacDonald, D., Coleman, J., Barrett, A. J. (1988). Q fever following bone marrow transplantation. Bone Marrow Transplant., 3 (2), 165-166.

Kersh, G. J., Priestley, R., Massung, R. F. (2013). Stability of Coxiella burnetii in stored human blood. Transfusion, 53 (7), 1493-1496.

Koehler, L. M., Kloppert, B., Hamann, H.-P., El-Sayed, A., Zschöck, M. (2019). Comprehensive literature review of the sources of infection and transmission routes of Coxiella burnetii, with particular regard to the criteria of "evidence-based medicine". Comp. Immunol. Microb., 64, 67-72.

Larson, C. L., Beare, P. A., Voth, D. E., Howe, D., Cockrell, D. C., Bastidas, R. J., Valdivia, R. H., Heinzen, R. A. (2015). Coxiella burnetii effector pro- 
teins that localize to the parasitophorous vacuole membrane promote intracellular replication. Infect. Immun., 83 (2), 661-670.

Le Jeune, J., Kersting, A. (2010). Zoonoses: An occupational hazard for livestock workers and a public health concern for rural communities. J. Agric. Saf. Health. 16 (3), 161-179.

Maurin, M., Raoult, D. (1999). Q fever. Clin. Microbiol. Rev., 12 (4), $518-553$.

McCaughey, C., McKenna, J., McKenna, C., Coyle, P. V., O’Neill, H. J., Wyatt, D. E., Smyth, B., Murray, L. J. (2008). Human seroprevalence to Coxiella burnetii (Q fever) in Northern Ireland. Zoonoses Public Hlth., 55 (4), 189-194.

Milazzo, A., Hall, R., Storm, P. A., Harris, R. J., Winslow, W., Marmion, B. P. (2001). Sexually transmitted Q fever. Clin. Infect. Dis., 33 (3), 399-402.

Mori, M., Roest, H.-J. (2018). Farming, Q fever and public health: Agricultural practices and beyond. Arch Public Health, 76 (1), 2.

Neare, K., Janson, M., Hütt, P., Lassen, B., Viltrop, A. (2019). Coxiella burnetii antibody prevalence and risk factors of infection in the human population of Estonia. Microorganisms, 7 (12), 629.

Oei, W., Kretzschmar, M. E. E., Zaaijer, H. L., Coutinho, R., van der Poel, C. L., Janssen, M. P. (2014). Estimating the transfusion transmission risk of Q fever. Transfusion, 54 (7), 1705-1711.

OIE (World Organisation for Animal Health). (2018). Q-fever. In: Manual of Diagnostic Tests and Vaccines for Terrestrial Animals 2019. OIE, Paris, pp. 560-577.

Osorio, S., Sarriá, C., González-Ruano, P., Casal, E. C., García, A. (2003). Nosocomial transmission of Q fever. J. Hosp. Infect., 54, 162-163.

Parker, N. R., Barralet, J. H., Bell, A. M. (2006). Q fever. Lancet, 367 (9511), 679-688

Pouquet, M., Bareille, N., Guatteo, R., Moret, L., Beaudeau, F. (2020). Coxiella burnetii infection in humans: To what extent do cattle in infected areas free from small ruminants play a role? Epidemiol. Infect., 148, E232.

Raoult, D., Tissot-Dupont, H., Foucault, C., Gouvernet, J., Fournier, P. E., Bernit, E., Stein, A., Nesri, M., Harle, J. R., Weiller, P. J. (2000). Q fever 1985-1998. Clinical and epidemiologic features of 1,383 infections. Medicine, 79 (2), 109-123.

Sellens, E., Bosward, K. L., Norris, J. M., Wood, N., Heller, J., Graves, S., Gidding, H. F. (2020). Coxiella burnetii seroprevalence in unvaccinated veterinary workers in Australia: Evidence to support Q fever vaccination Zoonoses Public Hlth. 67 (1), 79-88.

Shannon, J. G., Heinzen, R. A. (2009). Adaptive immunity to the obligate intracellular pathogen Coxiella burnetii. Immunol. Res., 43 (1-3), $138-148$.

Slot, E., Hogema, B. M., Molier, M., Zaaijer, H. L. (2014). Screening of blood donors for chronic Coxiella burnetii infection after large Q fever outbreaks. Transfusion, 54 (11), 2867-2870.

Social Science Statistics. (2020). http://www.socscistatistics.com/ (accessed 07.12.2020).

SPKC. (2020). Centre for Disease Prevention and Control of Latvia. https://spkc.gov.lv (accessed 08.12.2020).

Szymańska-Czerwińska, M., Galińska, E. M., Niemczuk, K., Knap, J. P. (2015). Prevalence of Coxiella burnetii infection in humans occupationally exposed to animals in Poland. Vector-Borne Zoonot., 15 (4), 261-267.

Tissot-Dupont, H., Amadei, M. A., Nezri, M., Raoult, D. (2004). Wind in November, Q fever in December. Emerg. Infect. Dis., 10 (7), 1264-1269.

Tokarska-Rodak, M., Weiner, M., Szymańska-Czerwińska, M., Pańczuk, A., Niemczuk, K., Sroka, J., Różycki, M., Iwaniak, W. (2018). Seroprevalence of selected zoonotic agents among hunters from Eastern Poland. Pol. J. Microbiol., 67 (2), 233-236.

Valencia, M. C. S., Rodriguez, C. O., Puńet, O. G., de Blas Giral I. (2000). Q fever seroprevalence and associated risk factors among students from the Veterinary School of Zaragoza, Spain. Eur. J. Epidemiol., 16, 469-476.

Van der Hoek, W., Dijkstra, F., Schimmer, B., Schneeberger, P., Vellema, P., Wijkmans, C., ter Schegget, R., Hackert, V., van Duynhoven, Y. (2010). Q fever in the Netherlands: An update on the epidemiology and control measures. Euro Surveill., 15 (12), 19520.

Van der Hoek, W., Hunink, J., Vellema, P., Droogers, P. (2011a). Q fever in the Netherlands: The role of local environmental conditions. Int. J. Environ. Heal. R., 21 (6), 441-451.

Van der Hoek, W., Meekelenkamp, J. C. E., Leendersm A. C. A. P., Wijers, N., Notermans, D. W., Hukkelhoven, C. W. P. M. (2011b). Antibodies against Coxiella burnetii and pregnancy outcome during the 2007-2008 Q fever outbreaks in the Netherlands. BMC Infect. Dis., 11, 44.

Voth, D. E., Heinzen, R. A. (2007). Lounging in a lysosome: The intracellular lifestyle of Coxiella burnetii. Cell. Microbiol., 9 (4), 829-840.

Received 8. January 2021

Accepted in the final form 18 May 2021

\section{PILOTPĒTĪJUMS PAR RISKA GRUPU CILVĒKU SEROPREVALENCI PRET COXIELLA BURNETII (Q DRUDZI) LATVIJĀ}

Q drudzis ir nozīmīga zoonotiska slimība visā pasaulē. Galvenie cilvēku inficēšanās avoti ir Coxiella burnetii baktēriju saturošu aerosolu ieelpošana un saskarsme ar inficētiem materiāliem dzemdību vai kaušanas laikā. Paaugstināta riska grupā ietilpst cilvēki, kuri strādā ar inficētiem mājlopiem, piemēram, lauksaimnieki, veterinārārsti, veterinārmedicīnas studenti, kautuvju un laboratorijas darbinieki. Rakstā iepazīstinām ar pilotpētījumu par riska grupu cilvēku seroprevalenci pret $C$. burnetii Latvijā. Pētījumā tika iekḷauti 240 asins seruma paraugi - 190 no riska grupām un 50 no kontroles grupas. Paraugi tika analizēti ar Coxiella burnetii (Q-fever) 1. un 2. fāzes IgG ELISA komplektiem. Visi kontroles grupas serumi bija negatīvi. Seroprevalence riska grupas personu vidū bija 8,04-11,54\%. Starp dzimumiem statistiski nozīmīgas atškirības netika novērotas. Vislielākais seropozitīvo un aizdomīgo serumu paraugu īpatsvars (25\%) tika konstatēts 39-48 gadu un 49-58 gadu vecuma kategorijās. Darbs kā praktizējošam veterinārārstam vai bijušajam veterinārārstam bija vienīgais riska faktors, kas identificēts kā statistiski nozīmīgs, kā arī piederība pie riska grupas kopumā. Seropozitīvo riska grupas dalībnieku ğeogrāfiskais sadalījums norādīja, ka to īpatsvars ir augstāks valsts ziemeḷu, centrālajā un austrumu dạ̣ā. 